\title{
Morphological and molecular analysis of indigenous Myanmar mango (Mangifera indica L.) landraces around Kyaukse district
}

\author{
May Sandar Kyaing April Nwet Yee Soe $\cdot$ Moe Moe Myint $\cdot$ Honey Thet Paing Htway $\cdot$ Khin Pyone Yi \\ Seinn Sandar May Phyo $\cdot$ Nwe Nwe Soe Hlaing
}

Received: 13 March 2019 / Revised: 14 March 2019 / Accepted: 3 April 2019

(c) Korean Society for Plant Biotechnology

\begin{abstract}
There is vast genetic diversity of Myanmar Mangoes. This study mainly focused on indigenous thirteen different mango landraces cultivated in central area of Myanmar, Kyauk-se District and their fruit characteristics by 18 descriptors together with genetic relationship among them by 12 SSR markers. Based on the morpho-physical characters, a wide variation among accessions was found. Genetic characterization of thirteen mango genotypes resulted in the detection of 302 scorable polymorphic bands with an average of 4.33 alleles per locus and an average polymorphism information content (PIC) of 0.7. All the genotypes were grouped into two major clusters by UPGMA cluster analysis and a genetic similarity was observed in a range of $61 \sim 85 \%$. This study may somehow contribute insights into the identification of regional mango diversity in Myanmar and would be useful for future mango breeding program.
\end{abstract}

Keywords Mango, fruit morphological characters, genetic analysis, Kyauk-se District

\section{Introduction}

Mango (Mangifera indica L.) belonging to the family Anacardiaceae is one of the most important tropical fruit crops around the world. It is believed to have originated from the Indo-Burma region (De Candolle 1984; Mukherjee 1951) during the earlier period of the Cretaceous era (Yonemori et al. 2002) and gradually spread to the tropical and subtropical regions of the world. It is considered to be a diploid fruit tree with $2 \mathrm{n}=40$ chromosomes and commonly

M. S. Kyaing $(\bowtie) \cdot$ A. N. Y. Soe $\cdot$ M. M. Myint $\cdot$ H. T. P. Htway $\cdot$ K. P. Yi - S. S. M. Phyo $\cdot$ N. N. S. Hlaing Molecular Genetics Laboratory, Biotechnology Research Department, Kyaukse District 05051, Myanmar e-mail: maysandar1207@gmail.com known as 'The King of fruits' in Asia. As mango has rich germplasm diversity due to its outbreeding nature and a wide range of agro climatic conditions, there are about 1600 varieties in the world (Pandey 1998). In Myanmar, mangoes are one of the peoples' choicest fruits due to its agronomic and cultural value and Myanmar mangoes are assumed to be traditional varieties or landraces as it has historical origin, distinct identity, genetically diverse, locally adapted and associated with traditional farming systems (Hirano R et al. 2011). Besides, it is considered to have a large number of local landraces exhibiting considerably a wide genetic variation in Myanmar. Usually, mango can be cultivated in many areas of Myanmar especially in southern region (Ayeyarwaddy, Bago and Yangon Divisions), in the central region (Mandalay and Sagaing Divisions) and in the east region (Southern Shan State). In 2013, the total planted area for mango in Myanmar was $(93,890)$ hectares and it was $30 \%$ of total cultivated area for fruits (MFFVPEA 2013). When it concerns to export, mango is the second priority after watermelon as well as favorite fruit for local consumption. There are about 300 different mango varieties and 20 kinds of mango species in Myanmar and among them, exportable quality mangoes with high sweetness level are 'Sein Ta Lone', 'Yin Kwel', 'Shwe Hin Thar','Mya Kyauk' 'Padamyar Nga Mauk' and 'Ma Chit Su'. These cultivars are mainly produced in the central and east region, and the production of mango from the remaining planting areas is usually for local consumption (Soe 2006, Win 2008). The Department of Agriculture Research (DAR) under the Ministry of the Agriculture and Irrigation, Myanmar is being carried out conserving mango diversity and over 75 mango varieties' germplasm were conserved in 2012 (MFFVPEA 2013).

Identification of varietal accessions is extremely important for conservation of genetic resources, germplasm management 
and regional diversity. There are different methods such as morphological, biochemical and molecular markers to characterize varietal heterogeneity of cultivars. There may be confusion in the assessment of intra- and inter-varietal variability with only classical approaches such as characterization of morphological traits because mango is crosspollinated crop, propagation by seed/clonal propagation using different mother tree sources and has sensitivity to changes in accordance with other environmental factors. In recent years, application of molecular marker technology has proven to be valuable tools in plant breeding programmes because of their high ability for showing diversity among the genotypes. Various molecular genetic markers such as Random amplified Polymorphic DNAs (RAPDs) (Karihaloo et al. 2003), Amplified Fragment Length Polymorphisms (AFLPs) (Kashkush et al. 2001), Inter Simple Sequence Repeats (ISSRs) (Sagar et al. 2007) and Simple Sequence Repeats (SSRs) (Ravishankar et al. 2011, Dillon et al. 2013) are widely used as a powerful tool for identifying inter/ intracultivar heterogeneity in mangoes. Among them, Simple sequence repeats (SSRs) have become the markers of choice for DNA fingerprinting purposes in most plant species due to their high polymorphism, reproducibility and codominant nature (Viruel et al. 2005). Therefore, morphological analysis together with molecular characterization is essential for better understanding of genetic diversity (Begum et al. 2012).

Kyauk-se region, which is situated in the central area of Myanmar, is famous for its indigenous mango variety, "Sein Ta Lone" and other popular mango varieties have been cultivated in mango orchards around Kyauk-se district. Grafting method was frequently found in clonal propagation of Myanmar Mango variety especially Sein Ta Lone for the maintenance of its genetic integrity and fruit quality. Depending on the cultivated areas, different names were probably given for some single cultivars of mangos which made it difficult for varietal identification. Therefore, it is needed to analyze genetic variability and relatedness among Myanmar mango accessions with the use of molecular markers together along with the analysis of their morphological characters. However, there are few reports of varietal identification and relationship based on their morphophysiological traits and genetic characteristics among mango cultivars in Myanmar. Hirano R et al (2010) has studied the genetic uniqueness of 62 Myanmar mango germplasm and observed a considerable genetic variation among them compared with varieties from Florida, India and Southeast Asia. Although that study exhibited a broad genetic background and genetic distinctiveness of Myanmar mango and
8 varieties had the same names of the current study, there were only two genotypes that were collected from central region of Myanmar. The main objectives of this research work were to characterize and evaluate morphological fruits characteristics and to assess the genetic variability of 13 indigenous popular mango cultivars cultivated in Kyaukse district, Myanmar using microsatelliltes (SSR) markers. Characterization, evaluation and documentation system for Myanmar mango will be invaluable for manipulating management of mango landraces, production, genetic conservation and further breeding program.

\section{Materials and Methods}

\section{Sample collection}

With simple random sampling strategy, physiologically mature fruits spread over all the sides of the tree canopy and leaves samples from each tree were harvested from mango orchards around Kyauk-se district and a total of 13 mango varieties were collected. Sampling and morphological characterization was conducted during the main mango harvest season from April to July 2018. The collected fruits and leaves sample were maintained in the ice box to be transported from the collection sites to Molecular Genetics Lab, Biotechnology Research Department, Kyaukse. Local mango accession names together with collection sites and regions around Kyauk-se district were listed in Table 1.

\section{Morphological Characterization}

The morpho-physiological characters of sterilized mangoes were evaluated at naturally ripening stage by descriptors for mango (IPGRI, 2006). For quantitative trait, 10 descriptors for fruit weight ( $\mathrm{g}$ ), pulp weight $(\mathrm{g})$, shell weight $(\mathrm{g})$, stone weight $(\mathrm{g})$, fruit length $(\mathrm{cm})$, fruit width $(\mathrm{cm})$, peel $(\%)$, pulp (\%), stone (\%), total soluble solids (TSS) ( ${ }^{\circ}$ Brix), were recorded. TSS (\%) was evaluated with the aid of a portable hand refractometer. In addition, 8 different qualitative traits of mangoes such as fruit shape, fiber content, pulp color, pulp aroma, pulp texture, skin color, skin thickness and eating quality were analyzed. Fruit skin thickness $(\mathrm{cm})$ was determined by using a vernier caliper. The mean data of thirteen mango accessions was analyzed following 'Descriptive Statistics' for mean, standard error, standard deviation and coefficient of variation. 
Table 1 Sample identifications (Sample ID), local names of thirteen local mango samples collected around Kyaukse District, Myanmar

\begin{tabular}{|c|c|c|c|c|c|}
\hline No. & Accession & Local Mango Names (genotypes) & Collection site & Region & District \\
\hline 1. & $\mathrm{AD}$ & Aung Din & U Htun Hla Orchard & Kyaukse & Kyaukse \\
\hline 2. & PS & Pan Swae & U Htun Hla Orchard & Kyaukse & Kyaukse \\
\hline 3. & YK & Yin Kwae & Mi Ba Myit Tar Orchard & Sintgaing & Kyaukse \\
\hline 4. & $\mathrm{NM}$ & Padamyar Nga Mauk & Shwe Nyi Ko Orchard & Sintgaing & Kyaukse \\
\hline 5. & HT & Shwe Hin Thar & Mi Ba Myit Tar Orchard & Sintgaing & Kyaukse \\
\hline 6. & PSP & Pan Sin Paung & Thazin Nwe Orchard & Paleik & Kyaukse \\
\hline 7. & MK & Mya Kyauk & Sandaku Orchard & Myittha & Kyaukse \\
\hline 8. & PBL & Pan Bingalar & Thazin Nwe Orchard & Paleik & Kyaukse \\
\hline 9. & MT & Mal Thi & Thazin Nwe Orchard & Paleik & Kyaukse \\
\hline 10. & PL & Pa Lel & Daw Hla Khin Orchard & Sintgaing & Kyaukse \\
\hline 11. & MSY & Ma Saw Yin & Aung Shun Lae Orchard & Sintgaing & Kyaukse \\
\hline 12. & $\mathrm{KK}$ & Khaung Khyoe & U Htun Hla Orchard & Kyaukse & Kyaukse \\
\hline 13. & STL & Sein Ta Lone & Thazin Nwe Orchard & Paleik & Kyaukse \\
\hline
\end{tabular}

\section{Genomic DNA extraction}

Total genomic DNA was extracted from young and flushing leaves by using the hexadecyl trimethyl ammonium bromide (CTAB) method with some modifications described by Ravishankar et al. (2000). The extraction buffer consisted of $2 \%$ hexadecyl trimethyl ammonium bromide (CTAB); $0.1 \mathrm{M}$ tris- $\mathrm{HCl}(\mathrm{pH} 8) ; 0.02 \mathrm{M}$ ethylene diamine tetra-acetic acid (EDTA) (pH 8); $1.4 \mathrm{M} \mathrm{NaCl}, 3 \%$ (w/v) polyvinyl pyroridone (PVP-40) and $1 \%$ (v/v) $\beta$-mercaptoethanol. The DNA concentration and purity was determined by Nanophotometer (IMPLEN P330, UK). After gel electrophoresis with $0.8 \%$ agarose gel, the extracted genomic DNA was determined by comparing with size standard $1 \mathrm{~kb}$ DNA ladder (Takara, Japan).

\section{SSR-PCR amplification}

Out of 24 microsatellite markers were screened, 12 SSR markers were selected for further analysis based on clarity, scorability and reproducibility of banding patterns. Details of the microsatellite markers used in this study were listed in Table 2. Microsatellite screening and Polymerase chain reaction (PCR) amplification was carried out with $10 \mu \mathrm{L}$ reaction mixture containing $1 \mu \mathrm{L}$ of $10 \times$ PCR buffer, $0.8 \mu \mathrm{L}$ of $2.5 \mathrm{mM}$ dNTPs, $0.3 \mu \mathrm{L}$ of $5 \mathrm{U}$ Taq DNA polymerase, $0.5 \mu \mathrm{L}$ of each $10 \mu \mathrm{M}$ forward and reverse primers, $0.5 \mu \mathrm{L}$ of $50 \mathrm{ng} / \mu \mathrm{L}$ of template genomic DNA and $6.4 \mu \mathrm{L}$ of nuclease free water. And PCR reactions were accomplished in Thermocycler (Proflex, Singapore) under the following profile: initial denaturation of $5 \mathrm{~min}$ at $94^{\circ} \mathrm{C}$ followed by 30 cycles of $30 \mathrm{sec}$ at $94^{\circ} \mathrm{C}, 30 \mathrm{sec}$ at pairing temperature between $45 \sim 55^{\circ} \mathrm{C}$ (variable according to the primers in use), $1 \mathrm{~min}$ at $72^{\circ} \mathrm{C}$, and final extension of $5 \mathrm{~min}$ at $72^{\circ} \mathrm{C}$. Amplified PCR products were separated by $8 \%$ Polyacrylamide gel electrophoresis with $0.5 \times$ TBE buffer at $130 \mathrm{~V}$ (constant voltage) for $1 \mathrm{hr}$. The gel was stained in silver nitrate solution $(0.1 \%)$ and $0.4 \mathrm{M} \mathrm{NaOH}$ and $4 \%$ formaldehyde were used as a developer solution. The size of each band was determined by comparing with size standard 100 bp DNA ladder (Takara, Japan).

\section{Data Collection and Analysis}

Morphological data were analyzed statistically by using SPSS package program (version 16.0). Analysis of variance techniques (ANOVA) was used to test the overall significance of the collected morphological data, and LSD test (0.05) was utilized to compare the differences among the treatment.

Amplified bands were scored on the basis of their presence (1) or absence (0), separately for each accession of mango cultivars and each SSR primer. The sizes were estimated by using 100-bp Standard DNA ladder marker, which was run along with the amplified products. Polymorphic information content (PIC) was calculated as $\mathrm{PIC}=1-\Sigma \mathrm{pi}^{2}$ where $\mathrm{pi}$ is the frequency of the $\mathrm{i}^{\text {th }}$ allele according to Nei (1973) and the genetic similarity and similarity matrix were estimated according to Dice coefficient. The genetic distinctiveness and relationship within accessions was calculated using Jaccard's similarity coefficient and cluster analysis was generated using unweighted pair-group method with arithmetic means (UPGMA) features of (NTSYS)-pc software (version 2.1) statistical analysis package (Rohlf, 2000). 
Table 2 List of the 12 SSR markers used in this study

\begin{tabular}{|c|c|c|c|c|}
\hline No. & Name & 5'-3' sequence & $\mathrm{Ta}\left({ }^{\circ} \mathrm{C}\right)$ & Size Range of Alleles \\
\hline 1. & $\mathrm{Mn}-89$ & $\begin{array}{l}\text { F: CGCCGAGCCTATAACCTCTA } \\
\text { R: ATCATGCCCTAAACGACGAC }\end{array}$ & 45 & $110-140 \mathrm{bp}$ \\
\hline 2. & Mn-19 & $\begin{array}{l}\text { F: AATTATCCTATCCCTCGTATC } \\
\text { R: AGAAACATGATGTGAACC }\end{array}$ & 55 & $130-180 \mathrm{bp}$ \\
\hline 3. & Mn -84 & $\begin{array}{l}\text { F: TCTATAAGTGCCCCCTCACG } \\
\text { R: ACTGCCACCGTGGAAAGTAG }\end{array}$ & 55 & $210-350 \mathrm{bp}$ \\
\hline 4. & Mn-16 & $\begin{array}{l}\text { F: GCTTTATCCACATCAATATCC } \\
\text { R: TCCTACAATAACTTGCC }\end{array}$ & 55 & $150-180$ bp \\
\hline 5. & LMMA 8 & $\begin{array}{l}\text { F: CATGGAGTTGTTGATACCTAC } \\
\text { R: CAGAGTTAGCCATATAGAGTG }\end{array}$ & 55 & $250-310$ bp \\
\hline 6. & MiSHRS 39 & $\begin{array}{l}\text { F: GAACGAGAAATCGGGAAC } \\
\text { R: GCAGCCATTGAATACAGAG }\end{array}$ & 55 & $340-370 \mathrm{bp}$ \\
\hline 7. & $\mathrm{Mn}-36$ & $\begin{array}{l}\text { F: CCTCAАТСТСАСТCAАCA } \\
\text { R: ACСCCACAАТCAААCTAC }\end{array}$ & 45 & $220-300$ bp \\
\hline 8. & $\mathrm{Mn}-85$ & $\begin{array}{l}\text { F: GCTTGCTTCCAACTGAGACC } \\
\text { R: GCAAAATGCTCGGAGAAGAC }\end{array}$ & 53 & $250-310$ bp \\
\hline 9. & MngSSR-24 & $\begin{array}{l}\text { F: CGATGGACTTCATAAGAAGAG } \\
\text { R: GCTAGCAGAATCACCTTGGTC }\end{array}$ & 53 & $150-180 \mathrm{bp}$ \\
\hline 10. & MiIIHR04 & $\begin{array}{l}\text { F: CGTTTTTGACCCTCTTGAGC } \\
\text { R: CCGCATACTTCCCTTCACAT }\end{array}$ & 55 & $140-190 \mathrm{bp}$ \\
\hline 11. & MiL27 & $\begin{array}{l}\text { F: AAGACATCATGGCCACTTGAC } \\
\text { R: CGAAGACCATGGTGGATTA }\end{array}$ & 55 & $330-360$ bp \\
\hline 12. & $\mathrm{Mn}-83$ & $\begin{array}{l}\text { F: AGCTATCGCCACAGCAAATC } \\
\text { R: GTCTTCTTCTGGCTGCCAAC }\end{array}$ & 55 & $190-213 \mathrm{bp}$ \\
\hline
\end{tabular}

\section{Results and Discussion}

Morphological Characterization

In this research, we mainly focused on fruit characters for morpho-physiological analysis of thirteen popular mango landraces cultivated in Kyauk-se district, central area of Myanmar and studied their genetic relatedness by microsatellites markers. It was found that there are over 50 different mango varieties around Kyauk-se region. Among them, we collected and analyzed the morpho-physiological characteristics of thirteen popular mango varieties. The most variable and suitable fruit-related quantitative descriptors were weight parameters such as fruit, pulp, skin, stone and seed (Sennhenn et al. 2013). Gan et al. (1981) indicated that fruit weight $(\mathrm{g})$, peel $(\%)$, pulp (\%), stone (\%), fruit length $(\mathrm{cm})$ and fruit width $(\mathrm{cm})$ have widely been used in the investigation of mango genotypes. In this study, we tried to characterize all these traits and their detailed characteristics are described in Table (3, 4 and 5).

According to the results of mean, standard error, standard deviation and coefficient of variation (CV), it is obvious that there was a wide range of variation among thirteen mango accessions. The maximum coefficient of variation (CV\%) was in pulp weight $(58.61 \%)$ followed by fruit weight $(48.62 \%)$ shell weight $(37.71 \%)$ and stone weight (34.87\%) indicating wide genetic variability in these traits whereas minimum coefficient of variation was found in peel \% (the ratio of peel weight to total fruit weight) $(11.62 \%)$ followed by fruit width (11.64\%) among thirteen Myanmar mango accessions. Thant HM et al. (2013) studied morphological characterization of 77 Myanmar mango fruit germplasm with 9 descriptors in which $\mathrm{CV} \%$ for fruit weight was the highest (59.24\%) followed by stone length (38.25\%) and the minimum CV\% was found in stone thickness $(16.32 \%)$. Wide difference in fruit weight from $143.3 \mathrm{~g}$ (Aung Din varieties) to $686.7 \mathrm{~g}$ (Mya Kyauk cultivars) was found among thirteen varieties and $\mathrm{CV} \%$ for fruit weight was recorded as (48.62\%) in this study. Similarly, the average weight of fruit per cultivar was greatly varied from $108.0 \mathrm{~g}$ to $409.2 \mathrm{~g}$ in eight mango cultivars (Hamdard et al. 2004) as well as there was a wide range of fruit weight (181.33 g to $604.10 \mathrm{~g}$ ) in 10 clones of 'langra' mangoes in India (Anu et al. 2015).

The ratios of peel, pulp and stone contents to total fruit weight ranged from 11.15 to $21.49 \%, 55.75$ to $75.92 \%$ and 
Table 3 Quantitative data analysis of thirteen mango varieties [Least significant difference (LSD) level $=0.05$ ]

\begin{tabular}{|c|c|c|c|c|c|c|c|}
\hline No. & Name & Stone Weight (g) & Shell Weight (g) & TSS ( ${ }^{\circ}$ Brix $)$ & Fruit Width $(\mathrm{cm})$ & Fruit Length $(\mathrm{cm})$ & Fruit Weight (g) \\
\hline 1 & $\mathrm{AD}$ & $36.67 \pm 5.77$ & $26.67 \pm 5.77$ & $16.33 \pm 3.79$ & $18.33 \pm 0.50$ & $9.50 \pm 0.85$ & $143.33 \pm 15.27$ \\
\hline 2 & PS & $70.00 \pm 6.95$ & $43.33 \pm 5.77$ & $12.00 \pm 1.83$ & $23.60 \pm 0.66$ & $11.93 \pm 0.12$ & $330.00 \pm 3.30$ \\
\hline 3 & YK & $56.67 \pm 5.77$ & $40.00 \pm 6.42$ & $13.33 \pm 1.53$ & $21.37 \pm 1.50$ & $13.17 \pm 0.76$ & $283.33 \pm 55.07$ \\
\hline 4 & $\mathrm{NM}$ & $60.00 \pm 10.00$ & $56.67 \pm 15.27$ & $8.77 \pm 1.07$ & $24.17 \pm 1.89$ & $13.47 \pm 1.42$ & $300.00 \pm 10.00$ \\
\hline 5 & HT & $53.33 \pm 20.84$ & $50.00 \pm 10.00$ & $16.00 \pm 2.65$ & $21.50 \pm 0.5$ & $14.73 \pm 1.10$ & $320.00 \pm 34.64$ \\
\hline 6 & PSP & $43.33 \pm 20.81$ & $46.65 \pm 5.81$ & $12.83 \pm 1.26$ & $21.87 \pm 0.23$ & $10.27 \pm 0.64$ & $226.67 \pm 15.27$ \\
\hline 7 & MK & $96.67 \pm 20.83$ & $76.67 \pm 11.54$ & $16.67 \pm 1.53$ & $25.17 \pm 1.26$ & $19.33 \pm 2.31$ & $686.67 \pm 89.62$ \\
\hline 8 & PBL & $36.74 \pm 11.54$ & $33.33 \pm 5.81$ & $9.27 \pm 0.64$ & $18.67 \pm 0.42$ & $9.33 \pm 0.76$ & $163.33 \pm 5.77$ \\
\hline 9 & MT & $78.33 \pm 28.86$ & $58.33 \pm 2.85$ & $12.33 \pm 0.58$ & $20.33 \pm 1.04$ & $16.67 \pm 0.58$ & $376.67 \pm 25.16$ \\
\hline 10 & PL & $33.33 \pm 5.77$ & $33.33 \pm 5.78$ & $10.00 \pm 1.00$ & $18.47 \pm 1.29$ & $9.00 \pm 0.87$ & $160.00 \pm 17.32$ \\
\hline 11 & MSY & $53.33 \pm 5.77$ & $33.33 \pm 5.84$ & $17.00 \pm 1.73$ & $20.70 \pm 0.52$ & $9.53 \pm 0.30$ & $196.67 \pm 15.27$ \\
\hline 12 & KK & $46.67 \pm 5.73$ & $40.00 \pm 10.00$ & $16.02 \pm 1.30$ & $23.17 \pm 0.29$ & $9.80 \pm 0.40$ & $266.67 \pm 11.54$ \\
\hline \multirow[t]{5}{*}{13} & STL & $50.00 \pm 3.08$ & $33.33 \pm 5.84$ & $19.33 \pm 0.76$ & $22.17 \pm 0.76$ & $10.67 \pm 0.58$ & $266.67 \pm 15.27$ \\
\hline & Mean & 53.73 & 43.97 & 13.84 & 21.85 & 12.42 & 286.16 \\
\hline & $\mathrm{SD}$ & 18.74 & 16.58 & 3.43 & 2.54 & 3.32 & 139.13 \\
\hline & $\mathrm{SE}$ & 3.00 & 2.66 & 0.53 & 0.39 & 0.512 & 22.28 \\
\hline & $\mathrm{CV} \%$ & 34.87 & 37.71 & 24.82 & 11.64 & 26.72 & 48.62 \\
\hline
\end{tabular}

Table 4 Quantitative data analysis of the thirteen mango varieties [Least significant difference (LSD) level $=0.05$ ]

\begin{tabular}{cccccc}
\hline No. & Name & Pulp Weight $(\mathrm{g})$ & Stone $\%(\mathrm{w} / \mathrm{w})$ & Pulp \% $(\mathrm{w} / \mathrm{w})$ & Peel $\%(\mathrm{w} / \mathrm{w})$ \\
\hline 1 & AD & $80.00 \pm 10.00$ & $25.59 \pm 2.78$ & $55.75 \pm 1.71$ & $18.70 \pm 4.39$ \\
2 & PS & $216.67 \pm 5.77$ & $21.21 \pm 0.23$ & $65.66 \pm 1.75$ & $13.13 \pm 1.75$ \\
3 & YK & $186.77 \pm 40.33$ & $20.272 \pm 2.28$ & $65.25 \pm 4.93$ & $14.48 \pm 2.82$ \\
4 & NM & $183.33 \pm 15.33$ & $19.977 \pm 3.09$ & $61.23 \pm 6.73$ & $18.79 \pm 4.52$ \\
5 & HT & $226.57 \pm 41.63$ & $16.852 \pm 6.67$ & $70.74 \pm 10.08$ & $15.74 \pm 3.69$ \\
6 & PSP & $143.33 \pm 15.27$ & $19.031 \pm 8.11$ & $63.47 \pm 8.18$ & $20.68 \pm 3.21$ \\
7 & MK & $520.00 \pm 51.96$ & $13.992 \pm 1.37$ & $75.92 \pm 2.25$ & $11.15 \pm 0.23$ \\
8 & PBL & $96.67 \pm 5.77$ & $22.304 \pm 6.16$ & $59.31 \pm 5.52$ & $20.47 \pm 3.97$ \\
9 & MT & $240.00 \pm 17.32$ & $20.828 \pm 0.74$ & $63.75 \pm 2.81$ & $15.54 \pm 1.41$ \\
10 & PL & $90.00 \pm 17.32$ & $20.741 \pm 1.28$ & $55.93 \pm 4.49$ & $21.11 \pm 5.09$ \\
11 & MSY & $110.00 \pm 10.00$ & $27.116 \pm 1.88$ & $55.98 \pm 3.83$ & $16.90 \pm 2.03$ \\
12 & KK & $193.33 \pm 11.54$ & $17.491 \pm 1.95$ & $72.53 \pm 3.96$ & $15.11 \pm 4.26$ \\
13 & STL & $183.33 \pm 11.54$ & $18.792 \pm 1.10$ & $68.74 \pm 1.41$ & $12.47 \pm 1.63$ \\
& Mean & 190.00 & 19.317 & 64.368 & 16.840 \\
& SD & 111.36 & 5.139 & 5.139 & 7.477 \\
& SE & 17.83 & 0.793 & 0.793 & 1.154 \\
& CV\% & 58.61 & 26.60 & 26.60 & 11.62 \\
\hline
\end{tabular}

12.79 to $27.11 \%$, respectively. The measurement of pulp percent is an important parameter for evaluating the quality of cultivars. The range of pulp varies from 55.75 to $75.92 \%$ in collected varieties of the present study. Similarly, other recent studies also indicated that 52 to $82 \%$ of pulp percent variability in 10 different clones of langra' mangoes in India
(Anu et al. 2015), 56.70 to $85 \%$ in 101 mango cultivars (Kumar 1998) respectively. Coefficient of variation for stone weight among the collected cultivars was $37.19 \%$ and the similar result was found in that of 77 different Myanmar mango germplasm (39.25\%) (Thant HM et al. 2013). It was discovered that mango peels of all thirteen varieties 
Table 5 Qualitative data analysis of the thirteen mango varieties

\begin{tabular}{ccccccccccc}
\hline No. & Name & Shape & $\begin{array}{c}\text { Fiber } \\
\text { content }\end{array}$ & Pulp color & Pulp Aroma & Pulp Texture & Skin color & Skin Thickness & $\begin{array}{c}\text { Eating } \\
\text { quality }\end{array}$ \\
\hline 1 & AD & Reniform & No & Golden yellow & Strong & Soft & Golden yellow & Thin & Excellent \\
2 & PS & Reniform & No & Yellow & Intermediate & Intermediate & $\begin{array}{c}\text { Red blush over } \\
\text { greenish yellow }\end{array}$ & Medium & Good \\
3 & YK & Round & Yes & Yellow orange & Strong & Soft & Greenish yellow & Thick & Good \\
4 & NM & Round & Yes & Yellow orange & Strong & Soft & Yellow orange & Thin & Very Good \\
5 & HT & Reniform & Yes & light yellow & Intermediate & Soft & Yellow & Thick & Very Good \\
6 & PSP & Oblong & Yes & Yellow & Intermediate & Soft & Yellow & Thin & Good \\
7 & MK & Reniform & No & light yellow & Intermediate & Soft & Greenish yellow & Thin & Very Good \\
8 & PBL & Round & Yes & Yellow & Intermediate & Soft & Greenish yellow & Medium & Good \\
9 & MT & Oblong & No & Yellow & Intermediate & Soft & Greenish yellow & Thin & Good \\
10 & PL & Oblong & Yes & Yellow & Intermediate & Soft & Greenish yellow & Medium & Good \\
11 & MSY & Oblique & Yes & Yellow orange & Intermediate & Soft & Golden yellow & Medium & Good \\
12 & KK & Oblong & Yes & Golden yellow & Strong & Soft & Golden yellow & Thin & Good \\
13 & STL & Oval & No & Golden yellow & Strong & Soft & Yellow & Thin & Excellent \\
\hline
\end{tabular}

were between $11 \%$ and $22 \%$ of the total fruit weight and it was consistent with the other previous studies in which mango peels represented in the range of $7 \%$ to $24 \%$ of the whole fruit weight (Berardini et al. 2005) and $7.27 \%$ to $15.21 \%$ of mango peels in 10 different clones of langra' mangoes in India (Anu et al. 2015).

Interestingly, it was observed that the heaviest cultivar, $\mathrm{MK}$, has the maximum value of pulp percent $(75.92 \%)$ as well as the lowest value of stone percent $(13.99 \%)$ and peel percent $(11.15 \%)$ of the whole fruit weight when it compared with these traits of other collected varieties. Generally, it seems that the bigger the fruit, the greater the pulp content while stone size and peel weight gradually decrease in $\mathrm{MK}$ variety. However, there was no obvious correlation about these traits in other collected cultivars.

As to quantitative results, qualitative data also varied depending on the different varieties of mango with respect to fruit shape, skin, pulp color, pulp aroma, fiber content and skin thickness and were illustrated in Table 5. Pulp texture of almost all studied accessions was soft except PS and $\mathrm{AD}, \mathrm{YK}, \mathrm{NM}, \mathrm{KK}$ and $\mathrm{STL}$ accessions possessed strong aroma. Five types of shapes (reniform, Round, Oblong, Oblique and Oval) were observed among accessions and less of fiber content was found in $\mathrm{AD}$, PS, MK, MT and STL varieties. Concerning with pulp color, $\mathrm{AD}, \mathrm{KK}$ and STL showed golden yellow color whereas YK, NM, MSY occupied yellow orange color. The color of the fruit pulp was light yellow in PS, PBL, MT, PL and HT, MK and yellow in MT and PL, respectively. Regarding to fruit skin color, PS accession showed red blush over greenish yellow and the colors of greenish yellow, yellow orange, golden yellow and yellow were found among the collected accessions. It was observed that skin thickness of $\mathrm{AD}$, NM, MK, MT, KK, and STL was thin whereas that of YK, HT was thick. Medium thickness of ripe mangos' skin was found in PS, PBL, PL and MSY. Generally, all the studied accessions showed good eating quality in which $\mathrm{AD}$ and STL accessions possessed excellent eating quality.

High total soluble solids (TSS) content revealed high quality of fruit with respect to taste, aroma and sweetness. The minimum value of total soluble solids (TSS) ( ${ }^{\circ}$ Brix) was observed in Padamyar Nga Mauk (NM) $\left(8.77^{\circ}\right.$ Brix) while the maximum value was found in Sein Ta Lone (STL) $\left(19.33^{\circ}\right.$ Brix) among accessions. The range of TSS ( ${ }^{\circ}$ Brix) percent in 77 different mango germplasm at DAR (Department of Agricultural Research, Yezin), Myanmar was 10 to $25 \%$ (Thant HM et al. 2013). In this study, Sein Ta Lone cultivars showed the highest TSS contents (19.33 ${ }^{\circ}$ Brix) among accessions representing as the best quality of fruit in all thirteen cultivars. According to the IPGRI descriptors, pulp TSS value ( ${ }^{\circ}$ Brix) was very low in NM, PBL, PL accessions $(<10)$, that of PS, YK, PSP, MT was low (10.1-14), and AD, HT, MK, MSY, KK showed medium TSS value (14.1-18). The possibility of difference in morpho-physiological characterization from one cultivar to another might be due to their difference in genetic heterogeneity. These evaluation results of fruit quality and assessment will be useful for selection of better mango cultivars and germplasm management. 
Table 6 Characteristics of the 12 SSR primers on the basic of their genetic analysis on the thirteen mango cultivars around Kyauk-se district

\begin{tabular}{|c|c|c|c|c|c|c|c|c|}
\hline No. & Name & $\mathrm{Na}$ & PIC value & $\mathrm{Ae}$ & Ho & $\mathrm{He}$ & UHe & $\mathrm{F}$ \\
\hline 1. & $\mathrm{MN}-89$ & 4 & 0.798 & 3.1 & 0.564 & 0.7636 & 0.7865 & 0.261 \\
\hline 2. & $\mathrm{MN}-19$ & 5 & 0.870 & 3.99 & 0.4143 & 0.7065 & 0.7276 & 0.414 \\
\hline 3. & MN -84 & 6 & 0.820 & 3.53 & 0.7429 & 0.7159 & 0.7373 & -0.038 \\
\hline 4. & MN-16 & 5 & 0.790 & 2.55 & 0.4857 & 0.7221 & 0.7437 & 0.327 \\
\hline 5. & LMMA 8 & 4 & 0.716 & 2 & 0.4143 & 0.6857 & 0.7062 & 0.396 \\
\hline 6. & MiSHRS 39 & 2 & 0.500 & 1.91 & 0.2857 & 0.5091 & 0.5243 & 0.439 \\
\hline 7. & $\mathrm{MN}-36$ & 4 & 0.770 & 2.78 & 0.7143 & 0.6519 & 0.6714 & -0.096 \\
\hline 8. & $\mathrm{MN}-85$ & 5 & 0.750 & 2.9 & 0.7429 & 0.7675 & 0.7905 & 0.032 \\
\hline 9. & $\mathrm{MN}-24$ & 3 & 0.450 & 1.85 & 0.4286 & 0.4675 & 0.4815 & 0.083 \\
\hline 10. & MiIIHR04 & 6 & 0.860 & 1.85 & 0.5857 & 0.7675 & 0.7905 & 0.237 \\
\hline 11. & MiL27 & 5 & 0.420 & 2.38 & 0.6429 & 0.5896 & 0.6072 & -0.090 \\
\hline \multirow[t]{2}{*}{12.} & Mn 83 & 3 & 0.660 & 1.8 & 0.6429 & 0.6005 & 0.6185 & -0.071 \\
\hline & Average & 4.33 & 0.700 & 2.553 & 0.5553 & 0.6622 & 0.6821 & 0.158 \\
\hline
\end{tabular}

$\mathrm{Na}=$ numbers of Allele per locus, $\mathrm{Ae}=$ number of effective alleles, PIC=Polymorphic Information Content, Ho=Observed Heterozygosity, $\mathrm{He}=$ Expected Heterozygosity, UHe=Unbiased Expected Heterozygosity

Molecular Characterization and SSR Polymorphism

A set of 24 SSR primers were used for initial screening of mango cultivars, of which 12 primers (Table 2) were selected for further analysis depending on the polymorphism of all varieties. It was found that there was a wide variation in the range of polymorphic bands produced by these primers. Twelve SSR primers used in this study yielded a total 330 bands and 302 scorable polymorphic bands. Total number of alleles was 52 and average number of alleles for each primer was 4.33 after amplification of total genomic DNA from thirteen mango varieties. Generally, each primer could amplify 2 to 6 DNA bands and effective number of alleles was between 1.8 and 3.99. Primer Mn 84 and MiIIHR 04 generated the highest number of bands (6 bands) followed by Mn19, Mn16, Mn 85, and MiL27 while MiSHRS 39 showed the lowest number of DNA bands ( 2 bands). Among all selected twelve SSR markers, only two markers, Mn 24 and MiL27 showed low polymorphic information content (PIC) with 0.45 and 0.42 whereas the remaining SSR produced high PIC values. MiSHRS 39 gave moderate polymorphism among all tested SSR markers. The highest PIC (0.87) was discovered while MN 19 was used to amplify all the genotypes. The allele size of polymorphic bands ranged from 110 to $370 \mathrm{bp}$.

Mango is a highly cross-pollinated plant which could probably be pollinated from unknown mother plants and most cultivars with the desirable characters have been selected among naturally produced seedlings (Karihaloo et al. 2003). Most mango varieties grown in Myanmar are polyembryonic types (Bompad and Schnell 1997, Hirano $R$ et al. 2010) in which high abundance of zygotic seedlings could be found (Schnell and Knight 1992, Cordeiro et al. 2006) and these zygotic seedlings could contain different alleles that increase genetic diversity among the cultivars (Hirano R et al. 2010). The average expected heterozygosity on all cultivars was 0.66 ranging from 0.4675 (Mn 24) to 0.7675 (Mn 85 and MiIIHR 04) and a range of PIC value was from 0.42 to 0.86 with an average value of 0.7 demonstrating high heterogeneity and wide genetic variation among accessions. Similarly, Hirano R et al (2010) has studied the genetic uniqueness of 62 Myanmar mango germplasm with eleven microsatellites markers in which average PIC value was 0.706 ranging from 0.346 to 0.857 and unbiased expected heterozygosity was 0.698 exhibiting considerable genetic variation. Taken together, high level of genetic variation among Myanmar mango landraces was observed possibly due to differences in propagation methods during long history of mango cultivation.

\section{Cluster Analysis and Genetic Relationship}

The dendrogram was constructed by using UPGMA cluster analysis of NTSYS pc software ver 2.1 based on the allelic data obtained from 12 SSR markers (Fig. 1) and its similarity matrix between thirteen mango accessions was shown in Table 7. A significant genetic variation was discovered among the mango genotypes with a Jaccard's 


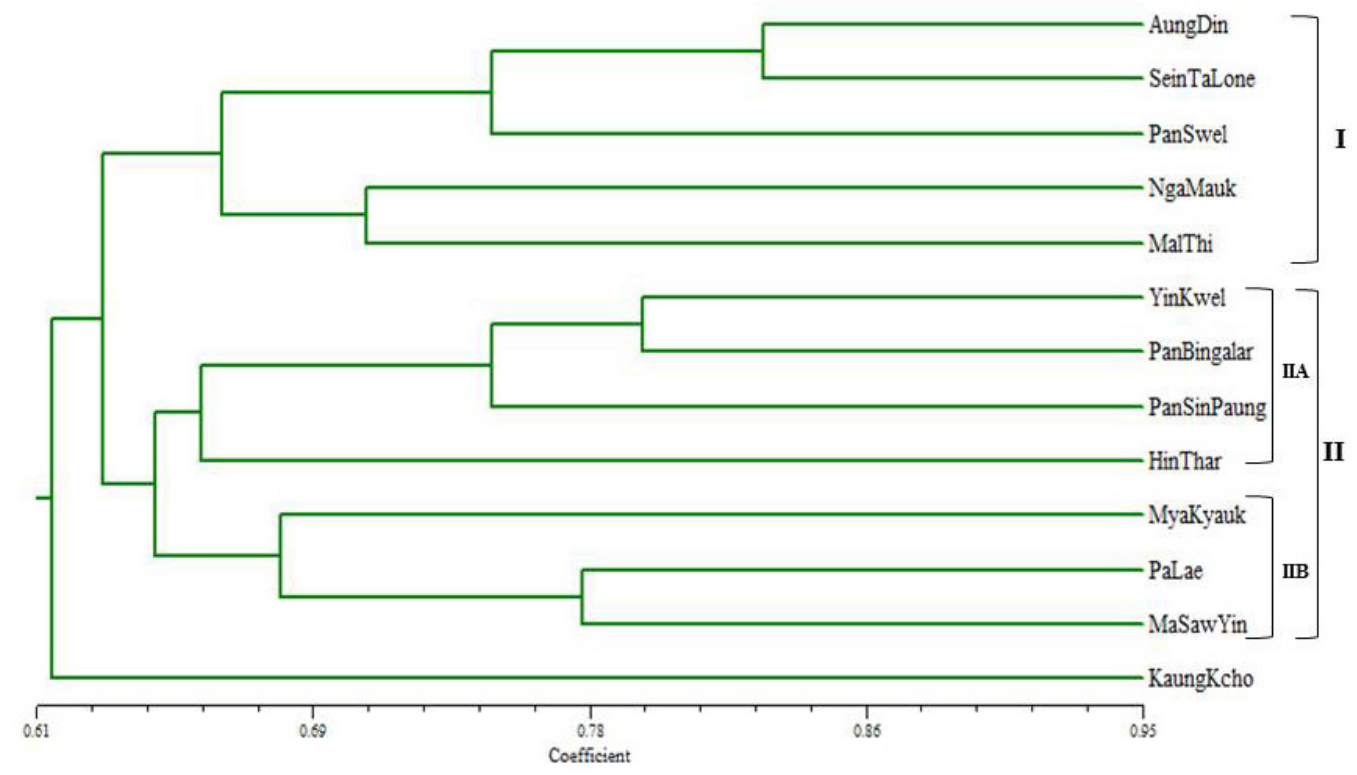

Fig. 1 UPGMA dendrogram showing genetic relationship between thirteen mango accessions based on the 12 SSR markers

Table 7 Pairwise similarity matrix for Jaccard's coefficient revealing a total of thirteen accessions of different mango genotypes

\begin{tabular}{|c|c|c|c|c|c|c|c|c|c|c|c|c|c|}
\hline $\begin{array}{c}\text { Rows } \backslash \\
\text { Columns }\end{array}$ & $\mathrm{AD}$ & PS & YK & $\mathrm{NM}$ & HT & PSP & MK & PBL & MT & PL & MSY & KK & STL \\
\hline $\mathrm{AD}$ & 1.000 & & & & & & & & & & & & \\
\hline PS & 0.722 & 1.000 & & & & & & & & & & & \\
\hline YK & 0.574 & 0.593 & 1.000 & & & & & & & & & & \\
\hline NM & 0.593 & 0.611 & 0.760 & 1.000 & & & & & & & & & \\
\hline HT & 0.593 & 0.648 & 0.685 & 0.630 & 1.000 & & & & & & & & \\
\hline PSP & 0.630 & 0.685 & 0.722 & 0.630 & 0.630 & 1.000 & & & & & & & \\
\hline MK & 0.500 & 0.593 & 0.555 & 0.574 & 0.611 & 0.537 & 1.000 & & & & & & \\
\hline PBL & 0.555 & 0.574 & 0.796 & 0.704 & 0.666 & 0.777 & 0.611 & 1.000 & & & & & \\
\hline MT & 0.635 & 0.712 & 0.654 & 0.712 & 0.635 & 0.635 & 0.538 & 0.596 & 1.000 & & & & \\
\hline PL & 0.648 & 0.704 & 0.741 & 0.685 & 0.611 & 0.611 & 0.704 & 0.722 & 0.654 & 1.000 & & & \\
\hline MSY & 0.648 & 0.666 & 0.630 & 0.611 & 0.759 & 0.611 & 0.666 & 0.615 & 0.615 & 0.777 & 1.000 & & \\
\hline KK & 0.555 & 0.574 & 0.685 & 0.630 & 0.555 & 0.666 & 0.737 & 0.630 & 0.635 & 0.685 & 0.537 & 1.000 & \\
\hline STL & 0.833 & 0.777 & 0.704 & 0.722 & 0.648 & 0.685 & 0.519 & 0.611 & 0.731 & 0.740 & 0.630 & 0.685 & 1.000 \\
\hline
\end{tabular}

$\mathrm{AD}=$ Aung Din, $\mathrm{PS}=$ Pan Swae, $\mathrm{YK}=$ Yin Kwae, $\mathrm{NM}=$ Nga Mauk, HT=Hin Thar, PSP=Pan Sin Paung, MK=Mya Kyauk, PBL=Pan Bingalar, MT=Mal Thi, PL=Pa Lae, MSW=Ma Saw Yin, KK=Khaung Kcho, STL=Sein Ta Lone

similarity coefficient ranging from 0.61 to 0.82 indicating that the percentage of genetic similarity between accessions was in the range of 61 to 82 . The dendrogram can be grouped into two major cluster (I and II) at similarity coefficient of 0.62 and cluster II could be subdivided into IIA and IIB exhibiting about $62 \sim 79 \%$ genetic similarity among each subgroup. KK (Khaung Kcho) variety seemed to be solitary and exhibited the lowest similarity level (61\%) among all genotypes.

The genetic relationship in Cluster I consisted of 5 varieties including $\mathrm{AD}$ (Aung Din), STL (Sein Ta Lone), PS (Pan Swel), NM (Nga Mauk) and MT (MalThi) in the range of 0.67 to 0.82 Jaccard's similarity coefficient. Interestingly, the highest genetic similarity $(82 \%)$ revealed by SSR analysis was discovered between Aung Din and Sein Ta Lone in the cluster I. Group IIA contained YK (Yin Kwel), PBL (Pan Bingalar), PSP (Pan Sin Paung) and HT (Hin Thar) with similarity coefficient of 0.65 to 0.79 in which YK and PBL possessed 79\% level of similarity within the group. Group II B included MK (Mya Kyauk), 
MSY (Ma Saw Yin) and PL (PaLae) showing a Jaccard's similarity coefficient ranging from 0.69 to 0.78 and PL (Palae) and MSY (Ma Saw Yin) showed 78\% level of similarity.

The occurrence of vast diversity in mango cultivars in this study might be due to a long period of cultivation, polyembryonic nature, germplasm exchange followed by much possibility of hybridization, high clonal heterozygosity. Application of different propagation methods is also one of the reasons for being heterogeneity in the study area during long time period of mango cultivation. Combination of both genetic study and morpho-physical characterization between thirteen local mango landraces might somehow provide useful information for background selection and identification of particular local landraces of mango. Investigation of considerable genetic variation between mango genotypes in Kyaukse region and identification of their relatedness has been exploited and it attributed a great insight for further genetic conservation, efficient utilization and proper selection of the better cultivars in Myanmar. Further assessment of genetic study for the remaining interand intra-cultivars of mango landraces in Myanmar is a prerequisite for the improvement of mango breeding program and germplasm management.

\section{Acknowledgements}

This work was carried out with the support of Biotechnology Research Department, Ministry of Education, Kyauk-se District, Myanmar.

\section{References}

Sennhenn A, Prinz K, Gebauer J, Whitbread A, Jamnadasso R, Kehlenbeck K (2013) Identification of mango (Mangifera indica L.) landraces from Eastern and Central Kenya using a morphological and molecular approach. Genetics Resources and Crop Evolution: doi 10.1007/s10722-013-0012-2

Anu A, Prasad BD, Kumar R, Kumar P, Patel V, Jha RN (2015) Clonal variability studies in 'langra' mango (Mangifera indica L.) using morphological, biochemical and molecular markers. International Journal of Agriculture, Environment and Biotechnology 8(3):567-581

Berardini N, Knodler M, Schieber A, Carle R (2005) Utilization of mango peels as a source of pectin and polyphenolics. Innovative Food Science \& Emerging Technologies 6(4): 442-452

Bompad, JM, and Schnell RJ (1997) Taxonomy and systematics. In the mango: botany, production and uses: 21-47
Cordeiro MCR, Pinto ACQ, Ramos VHV, Faleiro FG, and Fraga LMS (2006) Identification of plantlet genetic origin in polyembryonic mango Mangifera indica L. cv Rosinha seeds using RAPD markers. Revista Brasileira de Fruticultura 283: 454-457

De Candolle AP (1884) Origin of cultivated plants Hafner, London

Dillon NL, Baly ISE, Wright CL, Hucks L, Ines DJ, Dietzgen RG (2013) Genetic diversity of the Australian national mango genebank. Scientia Horticulturae 150:213-226

Gan YY, Zaini S and Idris A (1981) Genetic variation in the grafted vegetatively propagated mango (Mangifera indica). Pertanika Journal of Tropical Agricultural Science 4:53-62

Gajera H, Bambharolia RP, Rinkal D, Patel SV, Golakiya BA (2014) Molecular characterization and genetic variability studies associated with fruit quality of indigenous mango (Mangifera indica L.) cultivars. Plant Systematics and Evolution 300(5):1011-1020

Hamdard MS, Rafique R, Farooq U (2004) Physico-chemical characteristics of various mango (Mangifera indica L.) varieties. Journal of Agricultural Research 42(2): 128-132

Hirano R, Than Htun Oo, Watanabe KN (2010) Myanmar mango landraces reveal genetic uniqueness over common cultivars from Florida, India, and Southeast Asia. Genome 53: 321-330

Hirano R, Ishii H, Than Htun Oo, Gilani S, Kikuchi A, Watanabe KN (2011) Propagation management methods have altered the genetic variability of two traditional mango varieties in Myanmar as revealed by SSR. Plant Genetic Resources 9(3): 404-410 doi:10.1017/ S14792 62111000049

Thant HM, Nu TT, Thein MM (2013) Diversity of some mango (Mangifera indica L.) fruit germplasm in Myanmar. Proceedings of the Seventh Agricultural Research Conference, Yezin Agricultural University, Nay Pyi Taw, Myanmar. 140-149

IPGRI (2006) Descriptors for mango (Mangifera indica L.) International Plant Genetic Resources Institute, Rome

Karihaloo JL, Dwivedi YK, Archak S, Gaikwad AB (2003) Analysis of genetic diversity of Indian mango cultivars using RAPD markers. Journal of Horticultural Science and Biotechnology 78:285-289

Kashkush K, Jinggui F, Tomer E, Hillel J, Lavi U (2001) Cultivar identification and genetic map of mango (Mangifera indica). Euphytica 122:129-136

Kumar D (1998) Effect of post-harvest treatments on shelf-life and quality of mango. Indian Journal of Horticulture 55:134-138

MFFVPEA (2013) Fruit Calendar: Myanmar Fruit, Flower and Vegetables Producers and Exporters Association, UMFCCI, Yangon, Myanmar

Mukherjee SK (1951) Origin of mango Indian Journal of Genetics and Plant Breeding 11:49-56

Nei M(1973) Analysis of gene diversity in subdivided populations. Proceedings of the National Academy of Sciences of the United States of America 70(12): 3321-3

Pandey SN (1998) Mango cultivars. In Mango Cultivation, R.P. Srivastav (editor), International Book Distributing Company, Lucknow, India, 39-99

Ravishankar KV, Anand L, Dinesh MR (2000) Assessment of 
genetic relatedness among mango cultivars of India using RAPD markers. The Journal of Horticultural Science and Biotechnology 75(2):198-201, doi: 10.1080/14620316.2000. 11511223

Ravishankar KV, Mani BH, Anand L, Dinesh MR (2011) Development of new microsatellite markers from Mango (Mangifera indica) and cross-species amplification. American Journal of Botany 98:e96-e99

Ravishankar KV, Padmakar B, Bajpai A, Srivastava N, Mani BH, Vasugi C, Rajan S, Dinesh MR (2015) Genetic diversity and population structure analysis of mango (Mangifera indica $\mathrm{L}$.) cultivars assessed by microsatellite markers. Trees 29:775-783

Rohlf FJ (2000) NTSYS-pc: Numerical Taxonomy and Multivariate Analysis System Version 2.1 Exeter Publishing Setauket, New York

Sagar SP, Sirsha M, Ashok PG, Keshav HP, Bhimarao PP, Narayan DJ, Vidya SG (2007) Genetic diversity analysis of mango cultivars using inter simple sequence repeat markers. Current Science 93:1135-1141

Schnell, RJ, and Knight RJ (1992) Frequency of zygotic seedings from five polyembryonic mango rootstocks. Horticural Science
272:174-176

Soe TT (2006) Studies on Improved Methods of Postharvest Storage of Mango Fruits. PhD Thesis Dissertation, Graduate School of Agriculture, Tokyo University of Agriculture, Japan

Viruel M, Escribano P, Barbieri M, Ferri M, Hormaza J (2005) Fingerprinting, embryo type and geographic differentiation in mango (Mangifera indica L., Anacardiaceae) with microsatellites. Molecular Breeding 15(4):383-393

Win SS (2008) Commercially Mango Production and Trading, Ministry of Commerce, Nay Pyi Taw, Myanmar (Myanmar version) pp 43

Yamanaka N, Hasran M, He-Xu D, Tsunematsu H, Idris S, Ban T (2006) Genetic relationships and diversity of four Mangifera species revealed through AFLP analysis. Genetics Resources and Crop Evolution 53:949-954

Yonemori K, Honsho C, Kanzaki S, EiadthongW, Sugiura A (2002) Phylogenetic relationships of Mangifera species revealed by ITS sequences of nuclear ribosomal DNA and a possibility of their hybrid origin. Plant Systematics and Evolution 231:59-75 